\title{
Deforestation of watersheds of Panama: nutrient retention and export to streams
}

\author{
Ivan Valiela $\cdot$ Coralie Barth-Jensen • \\ Thomas Stone $\cdot$ John Crusius $\cdot$ Sophia Fox $•$ \\ Megan Bartholomew
}

Received: 4 September 2012/ Accepted: 26 February 2013/Published online: 19 March 2013

(C) The Author(s) 2013. This article is published with open access at Springerlink.com

\begin{abstract}
A series of eight watersheds on the Pacific coast of Panama where conversion of mature lowland wet forest to pastures by artisanal burning provided watershed-scale experimental units with a wide range of forest cover $(23,29,47,56,66,73,73,91$, and $92 \%)$. We used these watersheds as a landscape-scale experiment to assess effects of degree of deforestation on within-watershed retention and hydrological export of atmospheric inputs of nutrients. Retention was estimated by comparing rainfall nutrient concentrations (volume-weighted to allow for evapotranspiration) to concentrations in freshwater reaches of
\end{abstract}

Electronic supplementary material The online version of this article (doi:10.1007/s10533-013-9836-2) contains supplementary material, which is available to authorized users.

I. Valiela $(\bowtie) \cdot$ C. Barth-Jensen · M. Bartholomew

The Ecosystems Center, Marine Biological Laboratory,

Woods Hole, MA 02543, USA

e-mail: ivaliela@mbl.edu

\section{T. Stone}

Woods Hole Research Center, Falmouth, MA 02540, USA

J. Crusius

United States Geological Survey,

School of Oceanography, University of Washington,

Seattle, WA 98195, USA

S. Fox

Cape Cod National Seashore, National Park Service, Wellfleet, MA 02667, USA receiving streams. Retention of rain-derived nutrients in these Panama watersheds averaged 77, 85, 80, and $62 \%$ for nitrate, ammonium, dissolved organic N, and phosphate, respectively. Retention of rain-derived inorganic nitrogen, however, depended on watershed cover: retention of nitrate and ammonium in pasturedominated watersheds was 95 and $98 \%$, while fully forested watersheds retained 65 and $80 \%$ of atmospheric nitrate and ammonium inputs. Watershed forest cover did not affect retention of dissolved organic nitrogen and phosphate. Exports from more forested watersheds yielded DIN/P near 16, while pasture-dominated watersheds exported N/P near 2 . The differences in magnitude of exports and ratios suggest that deforestation in these Panamanian forests results in exports that affect growth of plants and algae in the receiving stream and estuarine ecosystems. Watershed retention of dissolved inorganic nitrogen calculated from wet plus dry atmospheric deposition varied from $90 \%$ in pasture- to $65 \%$ in forestdominated watersheds, respectively. Discharges of DIN to receiving waters from the watersheds therefore rose from $10 \%$ of atmospheric inputs for pasturedominated watersheds, to about $35 \%$ of atmospheric inputs for fully forested watersheds. These results from watersheds with no agriculture or urbanization, but different conversion of forest to pasture by burning, show significant, deforestation-dependent retention within tropical watersheds, but also ecologically significant, and deforestation-dependent, exports that are biologically significant because of 
the paucity of nutrients in receiving tropical stream and coastal waters.

Keywords Tropical watersheds · Forests · Pastures · Nitrogen · Phosphorus · Evapotranspiration ·

Groundwater

\section{Introduction}

Deforestation is a major agent of terrestrial ecosystem change in tropical latitudes (Wassenaer et al. 2007; Scanlon et al. 2007; Downing et al. 1999), and its consequences have regional- and global-scale effects on climate (Gash et al. 1996; IPCC 2007; Davin and Noblet-Ducoudre 2010), regional precipitation and water supply (Bosch and Hewlett 1982; Vorosmarty et al. 2000; Sun et al. 2006; Scanlon et al. 2007), and carbon sequestration (Wolf et al. 2011).

Deforestation also has numerous local ecosystemlevel effects that alter interception, sequestering, and transport of materials (Hirsch et al. 2004; Bruijnzeel 2004; Williams et al. 1997; Neill et al. 2001). Lower biomass reduces nutrient uptake and storage in temperate (Vitousek and Reiners 1975; Bormann and Likens 1979) and tropical forests (Williams et al. 1997), and increases nutrient exports. Where forest biomass is replaced with other land covers, such as pastures, lower biomass transpires less water, provides lower surface area for evaporative loss (Cleveland et al. 1999; Zhang et al. 2001; Nosetto et al. 2005; Li et al. 2007; Bahn et al. 2010), and allows greater water flow-through (Lewis et al. 1999; Lewis 2002). Loss of tropical forest cover lowers potential for microbial processes such as nitrogen fixation by diazotrophs on tree leaves, epiphytic orchids and bromeliads, litter, and soils (Downing et al. 1999; Cleveland et al. 1999; Roggy et al. 1999; Borbor-Cordova et al. 2006; Pons et al. 2007; Cusack et al. 2009), inputs that are difficult to measure (Cleveland et al. 2010; Reed et al. 2008). The litany of ecosystem-level effects can be expanded, but the foregoing suffices to suggest the fundamental impact of the pervasive tropical deforestation.

We identified a series of watersheds in the western part of the Pacific coast of Panama (Fig. 1) that had been subject to different degrees of conversion of forest to pastures, and could be considered as a readymade watershed-scale experiment to test effects of degree of deforestation on nutrient retention and

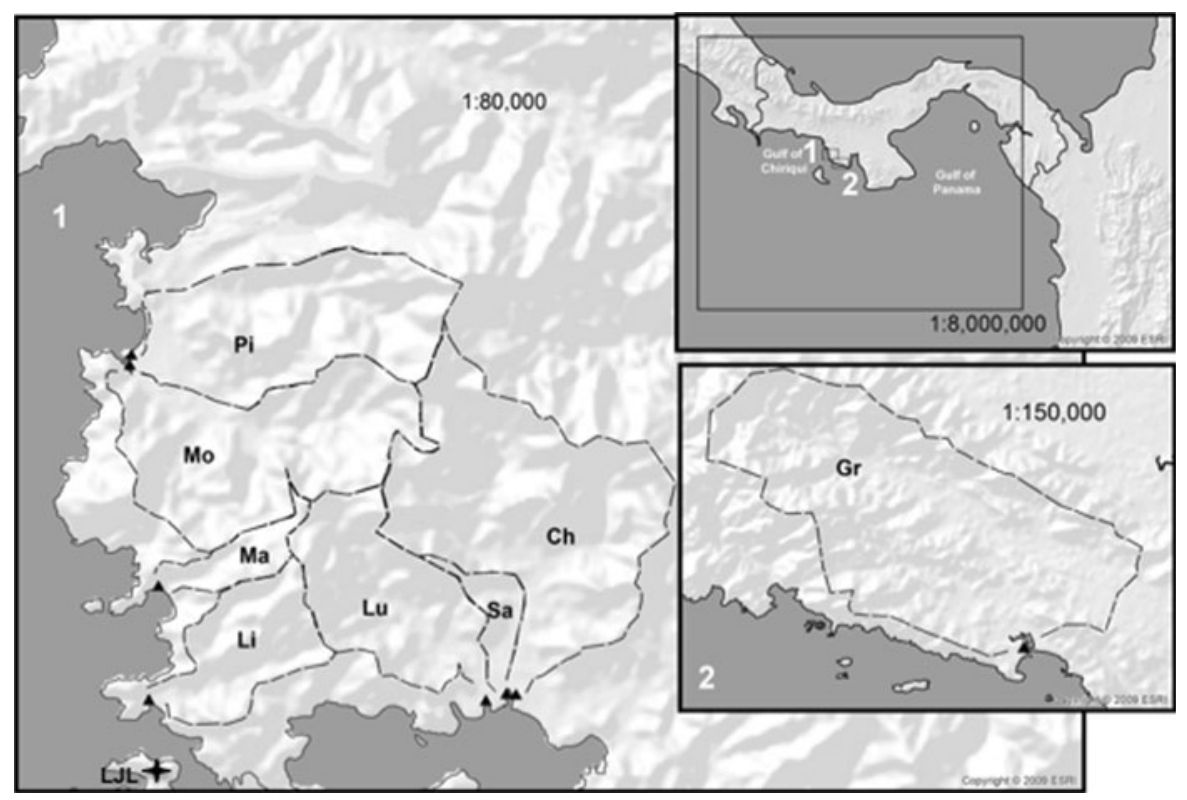

Fig. 1 Location of the study areas within Panama (top right), and maps of watersheds drained by each of the rios in the vicinity of the Liquid Jungle Laboratory (left) and the Rio Grande watershed (bottom right). Watershed bounds are indicated as dotted lines, and identified as $P$ Pixvae, Mo de la Mona, Ma Manglarito, Li Limon, Lu Luis, $S$ Salmonete, $C$ Chamuscado, and $G$ Grande. Location of the Liquid Jungle Laboratory denoted by a black cross and LJL 
export to receiving waters down-gradient. In this region deforestation takes place mainly by artisanallevel burning of small parcels of land, aimed at creating or maintaining pastures for livestock. This pattern is common throughout the tropics (Ewel et al. 1981; Kauffman et al. 1995; Chen et al. 2010). Bare soil created by burning is short-lived, with grasses growing aggressively within weeks of burning. Any shrubs and trees invading the deforested parcels are cut by hand with machetes by the parcel owner every other year or so. This management practice prevents succession from taking place.

In coastal regions there are powerful hydrologically mediated couplings among watersheds, and receiving streams, estuaries, and coastal waters. These couplings can be altered by changes in terrestrial land covers, and in the tropics, particularly by deforestation. One major mechanism involved in the coupling of coastal ecosystems is nutrient export from watersheds.

Exports of water and nutrients out of tropical watersheds may depend on the balance between supply and biological demand for specific nutrients on land (Vitousek and Howarth 1991; Downing et al. 1999; Perakis and Hedin 2002; Hedin et al. 2003; Brookshire et al. 2012). Many lowland tropical forests are P-limited (Davidson et al. 2007; Brookshire et al. 2012), with rain and nitrogen fixation furnishing $\mathrm{N}$ in excess of internal demand (Martinelli et al. 1999; Cleveland and Townsend 2006; Davidson et al. 2007). $\mathrm{N}$-limitation may occur in some tropical montane forests (Corre et al. 2010; Wullaert et al. 2010). LeBauer and Treseder (2008) report frequent N-limitation in tropical forests from a meta-analysis of fertilization experiments, mostly done in montane and recovering stands. Increased site age may also be associated with $\mathrm{N}-, \mathrm{N}$ and $\mathrm{P}$ co-limitation, and P-limitation of vegetation (Hedin et al. 2003). A long-term fertilization in mature lowland forest in Costa Rica showed that N, P, and $\mathrm{K}$ all played significant roles (Wright et al. 2011). The identity of limiting nutrients in tropical forests may therefore differ from one land parcel to another. Moreover, most of experimental evidence comes from contrasts between specific parcels with one or another land covers.

This paper assesses effects of deforestation on nutrient retention and export, taking advantage of the availability of Panamanian watersheds with different degree of deforestation to (1) expand the spatial scale to whole-watersheds with complex mosaics of vegetation, and (2) do so across a wide range of land cover conversion of forests to pastures. To evaluate inputs, retention, and export in these watersheds, below we estimate $\mathrm{N}$ and $\mathrm{P}$ concentrations in rain, groundwater, and freshwater reaches of receiving streams, and use these data to assess within-watershed retention and export from watersheds to receiving streams.

\section{Materials and methods}

Sites, watershed delineation, and estimation of deforestation on watersheds

We studied watershed-estuary landscape units along the Pacific coast of Veraguas Province, Panama (Fig. 1). The area is characterized by steep slopes, shallow soils, and a complex geology (Castroviejo and Ibañez 2005), with highly fractured underlying metamorphic rocks, volcanic basalts and gabbros. We acquired digital topographic sheets of the region from the Smithsonian Tropical Research Institute (http://mapserver.stri.si.edu; the maps used were Hoja Topográfica 1:50 k Veraguas Central TLM-50 NB1760 Defense Mapping Agency USA, and Hoja Topográfica 1:50 k Azuero Oeste TLM-50 NB1703 Defense Mapping Agency USA). These maps were imported into our GIS of the region. We then overlaid the digital topographic sheets onto very high resolution QuickBird satellite imagery, and manually digitized watershed boundaries into the GIS.

Each watershed is named after the watercourse (Rio) that drains it; these rios are largely springs, fed via lateral seepage of groundwater, with added surface runoff during intense rainstorms. Rainwater quickly flows into the very shallow soils in the region, and moves through the highly jointed and fractured underlying geological basement to recharge the aquifers. Eventually, groundwater seeps laterally into the rios, in highly spatially variable fashion. The uneven seepage must follow differences in flow conditions offered by the heterogeneous underlying geological material, with highly variable permeability, and occasional faster flow sites, perhaps what Chappell (2010) called "soil pipes".

The percent land covers within the watersheds were determined by logging point intercept hits on different land covers, from the crosshairs of a $100 \times 100 \mathrm{~m}$ 
grid overlain over QuickBird false color imagery. Repeat runs of the procedure on three watersheds produced highly reproducible results.

\section{Nutrient concentrations in rain}

To measure nutrients delivered by rain to watersheds, rainwater was collected in an open site near the Liquid Jungle Laboratory (Fig. 1) (www.liquidjunglelab.com), the headquarters for our work, during the entire year either in plastic acid-washed wide-mouth 41 bottles or in $500 \mathrm{ml}$ bottles with a $15 \mathrm{~cm}$-diameter collecting funnel. Nitrate, phosphate, and dissolved organic nitrogen were determined using standard colorimetric assays in a Lachat Auto Analyzer. Ammonium concentrations were determined by spectrophotometry. Checks showed that concentrations of nutrients in water collected using the two kinds of collectors did not differ.

\section{Nutrient concentrations in groundwater}

To measure nutrient concentrations in groundwater, we sampled in two ways. Samples of groundwater were obtained from springs emerging from the aquifers, in as many locations within each watershed as we could find by exploration and consultation with local villagers. These samples came from different locations away from the streams, and hence represented groundwater from different locations along flow paths from recharge points to discharge locations. We also collected groundwater nearing the receiving rios by driving a drive-point piezometer into the ground, at sites near the streams where the water table was shallow, taking care to avoid hyporheic flows, and withdrawing groundwater from depths of about $1-2 \mathrm{~m}$. We repeated the sampling during wet and dry seasons as feasible. Distances between groundwater sampling points and the margin of receiving waters ranged from a few $\mathrm{m}$ to a few $\mathrm{km}$.

\section{Nutrient concentrations in freshwater streams}

For this paper, we used some of the samples taken as part of a larger study that included estuaries and coastal waters of the region. In that work, we collected 3 replicate samples of stream or estuary water at each of 9 stations, from fresh headwaters to the mouth of the estuaries (Valiela et al. submitted). Each sample was collected through an acid-washed syringe, and filtered in the field through a $0.7 \mu \mathrm{m}$ glass-filter set in a handheld filter holder. The filtrate was expressed into acidwashed plastic vials that were kept in a cooler until arriving at the field station where they were frozen until analysis. For the present paper, however, we were interested in samples of water that had recently seeped into each stream. We only used samples with $<5 \%$ salinity, because there were no significant differences in concentrations of nutrients between samples with salinity of 0 and $5 \%$ (data not shown). Measurement of concentrations of nitrate, ammonium, dissolved organic nitrogen, and phosphate was as in the case of rainwater.

\section{Estimation of within-watershed retention}

To evaluate retention and interception of rain-derived nutrients within watersheds, we calculated the percent difference between rain-derived nutrient concentrations, relative to concentrations in water collected from fresh reaches of the rios that drain the watersheds included in this study (Table 1). We use "retention" here, as we had in earlier work on temperate watersheds (Valiela et al. 1992, 1997), as shorthand to refer to the joint effects of adsorption in soils and sediments, denitrification, net uptake in plants, and other processes that affect nutrient inputs derived from atmospheric deposition, such that the water-borne export out of the terrestrial part of the ecosystem is lower than the inputs.

Calculation of within-watershed retention required four steps. First, we volume-weighted concentrations of nutrients delivered by rain, to allow for the loss of volume of freshwater involved in ET. We have used this adjustment for volume lost via ET in dealing with nutrient budgets in temperate ecosystems (Valiela et al. 1997; Bowen et al. 2007), and validated the approach versus empirical estimates (Valiela et al. 2000; Bowen and Valiela 2001). The models that use the ET-adjusting procedure were tested versus other models that use fluxes instead of ET-adjusted concentrations, and have shown success in application to many other watersheds (Latimer and Charpentier 2010; Giordano et al. 2010). The volume weighting we used is equivalent to using fluxes to estimate retention.

Second, we assumed that recharged freshwater flows from watersheds into streams, with little 
Table 1 Areas and percent land covers in the watershed-estuaries included in this study

\begin{tabular}{|c|c|c|c|c|c|c|}
\hline \multirow[t]{2}{*}{ Watershed/estuary } & \multirow[t]{2}{*}{ Area of watershed (ha) } & \multicolumn{5}{|c|}{ Land cover $(\%)$} \\
\hline & & Forest & Pasture & Burned & Bare & Mangrove \\
\hline Pixvae & 1,429 & 73 & 23 & 2 & 1.4 & 1.4 \\
\hline De La Mona & 1,575 & 47 & 47 & 4.7 & 0.1 & 1.5 \\
\hline Manglarito & 239 & 91 & 6 & 1.8 & 0 & 0.4 \\
\hline Limon & 665 & 92 & 5 & 0 & 0 & 3 \\
\hline Luis & 1,007 & 73 & 18 & 5.2 & 0.3 & 3.5 \\
\hline Salmonete & 195 & 29 & 52 & 2 & 0 & 18 \\
\hline Chamuscado & 2,229 & 66 & 28 & 5 & 0.3 & 1.6 \\
\hline Grande & 9,639 & $23^{\mathrm{a}}$ & 43 & 31 & 0 & 2 \\
\hline
\end{tabular}

a More than half $(57 \%)$ of the forested area remaining in the Rio Grande watershed (23\% of the watershed area), consists of a narrow band of remnant gallery forest growing along stream shores

percolation to deep layers that may shunt some recharge out to sea. In some tropical areas with highly permeable aquifers there may be some flow to deep underlying layers (Charlier et al. 2008; GomezDelgado et al. 2011) that could then flow out to sea directly, without going through the rios. In contrast, Williams et al. (1997) estimated that in a Brazilian watershed, subsurface outflow was only about $1.5 \%$ of rainfall in a forested site, and $1.9 \%$ after the site was $80 \%$ deforested; change in inter-annual water storage in soils was of similar magnitude. We checked the possible underflow in our study areas in Panama, by pilot work with chamber flow meters and piezometer samples that failed to find groundwater underflow along the shorelines of the region (M. Charette, Woods Hole Oceanographic Institution, pers. comm.). We further checked possible deep outflow by a continuous survey of ${ }^{222} \mathrm{Rn}$ (a tracer for groundwater flow, Cable et al. 1996) run 50-200 $\mathrm{m}$ from shore, across the entire shoreline in the region of our watersheds. We found little evidence of deep groundwater underflows out of the watersheds into the sea; there was, on the other hand, clear ${ }^{222} \mathrm{Rn}$ evidence of substantial groundwater flow though the streams themselves (Crusius et al. in prep.). We therefore proceeded in the assumption that, as in the case of Williams et al. (1997), deeper subsurface flows were modest, and that fluxes into freshwater streams and down-gradient estuaries captured the large majority of freshwater exported from watersheds.

Third, as an independent ancillary check on the volume-adjusted calculations of concentrations, we compared them to the empirically measured concentrations of nutrients in groundwater.

Fourth, once we had volume-adjusted estimates of concentrations, and some assurance that recharged rainwater did indeed flow to the streams, we calculated the nutrient concentrations that would arrive at the edge of the rios, if there were no losses during transit through soils and aquifers. These estimates in turn could be compared to concentrations measured in water samples collected within the fresh upper reaches of the streams, and the percent difference was an estimate of the retention (or interception) that actually took place within the watersheds.

\section{Estimation of evapotranspiration}

To estimate nutrient concentrations that would arrive at the edge of receiving waters, barring withinwatershed losses, we estimated fluxes out of the watersheds by adjusting nutrient concentrations from rain samples to the account for the large volumes of water lost by ET. ET is necessarily estimated using models, and there is a degree of uncertainty in results. Published reports disagree as to the seasonal and interannual variation of ET (Hutyra et al. 2007; Hasler and Avissar 2007; Loescher et al. 2005; Heartsill-Scalley et al. 2007). We approximately estimated annual ET in the region of the present study in three different ways, based on published model results from tropical regions and local data.

First, we compiled 25 recently published estimates of ET for tropical sites across the world, obtained by 
application of Penman-Monteith (P-M) model approaches (Table S1). P-M models calculate ET based on expressions of empirically measured relevant local variables, such as leaf area index, albedo, soil moisture, temperature regimes, and so on [see, for example, Loescher et al. (2005) and Sumner and Jacobs (2005) for equations involved], in most cases aided by remote sensing information. We calculated a mean annual ET $( \pm \mathrm{se})$ for tropical watersheds from this compilation.

Second, we obtained another estimate of ET based on modeling for a part of Panama to the west of our region, produced by analysis of LANDSAT images done applying the Surface Energy Balance Algorithms for Land (SEBAL) model (Hendrickx et al. 2005), a remote-sensing based approach contrasting with the empirical on-site variable emphasis involved in use of P-M based models.

Third, we estimated ET from estimates of local rainfall, using a regression between rainfall and ET for forest-dominated tropical sites (Fig. S1). The regression was derived from a compilation of published sources (Table S1). We used the regression and additional information, as follows. To assess ET for forested landscapes in our area, we first estimated rainfall from detailed time- and spatially resolved precipitation data provided by the Tropical Rainfall Measuring Mission (TRMM, at http://trmm.gsfc.nasa. gov). We selected TRMM values from 2004 to 2010 for the area relevant to the watersheds in our study (Fig. S2), and averaged the selected data to obtain rain data during wet and dry seasons. Then, from seasonal TRMM rain data, and seasonal variation in ET for the area in Panama, reported in NASA's MODIS site (http://modis.gsfc.nasa.gov/data/dataprod/dataproducts. php/MOD_NUMBER=16), we used the literaturederived regression to estimate actual ET per season.

In view of the demonstrated lower ET associated with conversion of forests to pastures, it seemed advisable to adjust estimates of ET in some proportion to the ratio of forest and pastures found in each watershed included in Table 1. Li et al. (2007) modeled changes in ET that might follow tropical forest landscape conversion to pastures, much the same transition affecting the Panama watersheds. We selected values from simulations by Li et al. (2007), describing the percent reduction in ET associated with different degrees of conversion of forests to pastures, and plotted the points (Fig. S3); from this curve, we estimated correction values to be subtracted from the estimated forest ET, given the forest and pasture cover present in each watershed.

Adjusting to compensate for dry atmospheric nitrogen inputs

Values of nutrient retention we obtained from the empirical data collected were likely underestimates, because we lacked data on dry atmospheric deposition. To roughly include dry deposition in our estimates of retention and exports from the Panamanian watersheds, we adjusted for dry deposition using data compiled from the literature.

Bulk rainfall collections insufficiently capture dry deposition of aerosols, ions, and particulates (Lovett 1994; Lajtha et al. 1995). Dry deposition on temperate areas of eastern North America, for example, amount to $48 \%$ of nitrate deposition, and $18 \%$ of ammonium deposition (Bowen and Valiela 2001). Although some conclude that dry deposition is low in the tropics (Ahlm et al. 2010), measured ratios of dry to wet deposition fluxes in tropical latitudes range widely, from 0.11 to 1 (Clark et al. 1998; Baker et al. 2007; Boy et al. 2008; Wullaert et al. 2010), and dry deposition could be larger for rainforests (Hofhansl et al. 2010). Dry deposition should be a function of deforestation, since forests furnish greater area for dry deposition that grasslands, but we lacked data with which to assess such differences, so we used the one value for all watersheds. Mean of dry/wet values from these references was 0.55 , a correction term we used to adjust empirically measured bulk deposition to include dry deposition.

\section{Results and discussion}

Deforestation of watersheds

The land cover on watersheds included in this study ranged from 23 to $92 \%$ forested (Table 1). This broad span provided a reasonably wide range within which we could assess effects of conversion of forest to pastures on nutrient retention and export. The gradient in land cover involved was a shift between forest and pastures, since there were few other significant types of land covers in the region (Table 1), and, as mentioned, pastures were maintained by hand labor done by their owners to prevent succession. 
Nutrients in rain and effect of evapotranspiration

\section{Nutrients in rainfall}

Concentrations of nutrients in rain were consistently larger during the dry season compared to those during the wet season (Table 2). This effect could follow, as reported for elsewhere in the tropics (Sigha-Nkamdjou et al. 2003; Baker et al. 2006; Sundarambal et al. 2010; Chen et al. 2010), from the incidence of burning during the dry season (mainly done during March). Alternately, the seasonal difference could be by dilution owing to larger volume of more frequent rain during the wet season; we found, however, no relationship of concentrations and previous rain events (data not shown). In general, there was somewhat more nitrate than ammonium in rain, and far more dissolved organic nitrogen. Phosphate concentrations were uniformly low.

Nitrate and ammonium concentrations in atmospheric deposition reported for many tropical forested environments span wide ranges (Fig. 2), with modal concentrations about 3 and $4 \mu \mathrm{M}$ nitrate and ammonium, respectively, and an asymmetrical skew. Concentrations we measured in the Liquid Jungle Laboratory broadly overlapped concentrations found falling unto tropical sites. Variation in concentrations within a site, and from one rain event to the next,

Table 2 Concentration ( $\mu \mathrm{M}$, mean \pm se) of nitrate, ammonium, phosphate, and dissolved organic nitrogen during wet (Apr-Nov) and dry (Dec-Mar) seasons, 2009-2011, in rainwater collected at the Liquid Jungle Laboratory

\begin{tabular}{lllc}
\hline & $\begin{array}{l}\text { Wet } \\
\text { season }\end{array}$ & $\begin{array}{l}\text { Dry } \\
\text { season }\end{array}$ & Annual \\
\hline Nitrate & $4.8 \pm 1.9$ & $8.8 \pm 1.8$ & 5.3 \\
Ammonium & $3.5 \pm 1.2$ & $4.8 \pm 1.2$ & 3.7 \\
$\begin{array}{l}\text { Phosphate } \\
\text { Dissolved organic } \\
\text { nitrogen }\end{array}$ & $0.4 \pm 0.1$ & $1.3 \pm 0.5$ & 0.5 \\
$\mathrm{~N} / \mathrm{P}^{\mathrm{a}}$ & $16.3 \pm 4.5$ & $25.1 \pm 6.8$ & 17.4 \\
\hline
\end{tabular}

Annual concentrations were volume-weighted in proportion to rainfall during the two seasons, using precipitation data from TRMM (Fig. S2). The volume-weighted values were used in the retention calculations. N/P calculated as nitrate plus ammonium divided by phosphate concentrations

${ }^{\text {a }}$ N/P values differ slightly from what may be calculated from numbers in this table because the latter were rounded to one decimal
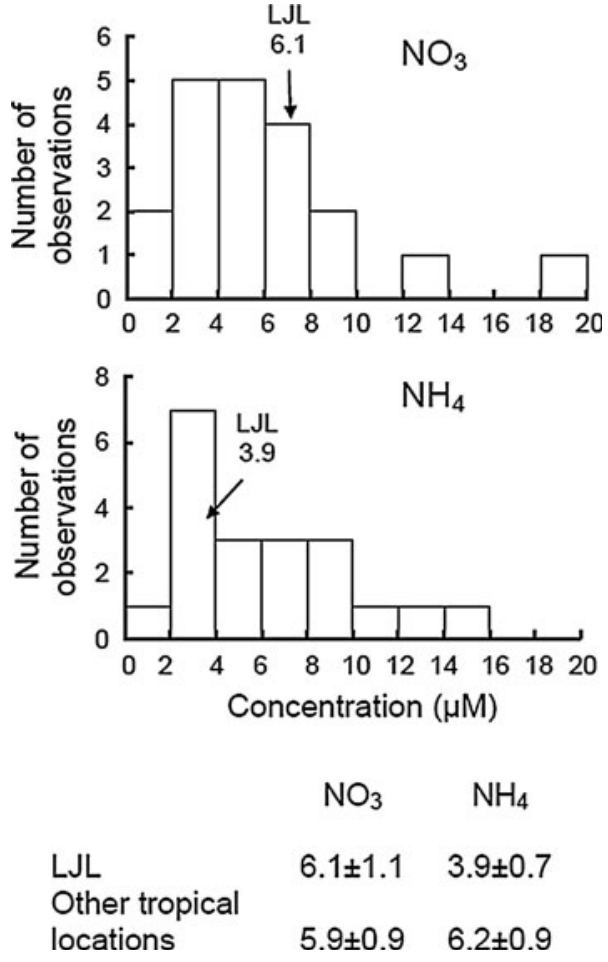

Fig. 2 Comparison of the mean concentrations of nitrate (top) and ammonium (middle) measured in rain collected at the Liquid Jungle Laboratory (LJL) and at various other tropical sites (data from sources in Table S1). The table on the bottom shows mean \pm se for the LJL and for the other tropical sites

seemed as large as geographic variation over large spatial scales (Fig. 2, table on bottom).

\section{Evapotranspiration estimates}

The estimates of actual ET obtained by the three different methods yielded reasonably similar values, within the range suggested by Loescher et al. (2005). In most neo-tropical wet forests receiving 2,400$3,000 \mathrm{~mm} \mathrm{year}^{-1}$ of rain, for example, about $50-60 \%$ of rainwater may be lost as ET, and the remainder flows through the watershed (Loescher et al. 2005). We estimated ET from 25 reports of ET for tropical sites worldwide, which provided a mean \pm se of $58 \pm 4 \%$ of rainfall (Table S1). SEBAL-derived estimates suggested that ET in forested Panama watersheds might reach $53-75 \%$ of precipitation; deforested sites might show ET as 35-43\% of rainfall. Therefore, ET in watersheds with mixed forest-pasture land covers would fall somewhere within these ranges. 
The third, and more site-specific estimate of ET, was that calculated from local rainfall and the regression fitted to published data on rain and ET from 24 tropical sites. This calculation provided an estimated ET of $52 \pm 22.1 \%$ of rain for our region (uncertainty calculated from residuals from regression, Fig. S1). Based on the more site-specific nature of the third estimation, and the corroborating ranges of the other two estimates of ET, we opted to use $\mathrm{ET}=52 \pm 22.1 \%$ of rainfall as a best estimate for forested watersheds for the region.

To assess the presumed dependency of ET on vegetation type, we used results from Li et al. (2007), who modeled the effects of shifts from tropical forest to pastures on ET, and found non-linear responses of canopy transpiration and soil and canopy evaporation to different degrees of deforestation of watersheds. For each watershed listed in Table 1, we used the equation of Fig. S3 to estimate a correction term based on the ratio of forest to pasture land cover in each watershed. The correction factors for our watersheds were small (mean $3.7 \%$, range $0.5-14 \%$ reductions in ET relative to ET of forested tracts), and fell well within uncertainty with which we estimated regional ET. The effect of pastures on ET in our watersheds was therefore minor, and we could have ignored the correction. We included the corrections to highlight, from Fig. S3, that where pasture covers are greater than we measured, the non-linear effects on ET could be more significant and should be considered, a point highlighted by $\mathrm{Li}$ et al. (2007), who found accelerated hydrological responses as land cover changes intensified.

We used the adjusted estimates of freshwater volumes to estimate volume-weighed nutrient concentrations that, barring within-watershed interception of atmospheric nutrients, should be arriving at the edge of receiving streams in each watershed. Below we compare these volume-adjusted concentrations to measured groundwater concentrations ( $x$ axis of left panels, Fig. 3), and to measured concentration in water samples taken from the fresh reaches of the streams leading into the estuaries (Fig. 4).

Nutrients in groundwater

To assess whether the adjusted rain-derived estimates were reasonable, we compared the adjusted values with measured concentrations in groundwater itself. Concentrations of nutrients in groundwater were consistently lower than those in volume-adjusted rainfall (Fig. 3, left column of panels), a pattern that confirms that within-watershed processes affected rain-derived nutrients. In turn, nutrient concentrations in groundwater were consistently larger than concentrations measured in fresh reaches of streams (Fig. 3, right column of panels). These results simultaneously suggested that the calculated adjusted concentrations were reasonable, and that there were additional processes (denitrification, adsorption, plant uptake) within soils, aquifers, or riparian zones that cumulatively diminished nutrient concentrations along transit through watersheds to receiving waters.

The variation in nutrient concentrations in groundwater was large enough to mask links between nutrient concentrations in groundwater and \% forest cover on watersheds (data not shown). The substantial variation in concentrations of groundwater nutrients (Fig. 3) may have resulted from the un-avoidable collection of groundwater samples at different distances along the flow-path from deposition site to the rios, and the spatially heterogeneous within-watershed processes that create local differences that are then maintained by low dispersion in groundwater. Large variation seems common for soil and groundwater nutrients. In a Peruvian Amazon wet forest concentrations of ammonium $(2.8 \pm 2.4 \mu \mathrm{M})$, nitrate $(2.8 \pm 2.4 \mu \mathrm{M})$, and phosphate $(0.11 \pm 4.39 \mu \mathrm{M})$ in groundwater had standard deviations as large or larger than the means (Saunders et al. 2006), as also found by Chaves et al. (2009).

Seasonal changes in groundwater nutrient concentrations (data not shown) were smaller than amongsample variation (Fig. 3 left panels), much as found in Brazil (Chaves et al. 2009), Peru (Saunders et al. 2006), and Puerto Rico (McDowell et al. 1992). It seems reasonable to find lack of seasonal variation because different nutrient travel times and exposure to within-watershed biogeochemical processes may overwhelm seasonal differences in inputs.

Nutrients in water of fresh reaches of receiving streams

Concentrations of nutrients in headwaters of the streams were variable (Table 3; Fig. 3, $y$ axis of right panels, and white points, Fig. 4). There was large variation in concentrations of nutrients and sites, but, as in the case of groundwater, and in contrast to 
Fig. 3 Left panels comparisons of adjusted concentrations in rainwater that enters the watershed (allowing for ET) versus concentrations measured in groundwater. Right panels comparisons of concentrations measured in groundwater versus concentrations in water that has just appeared in the upper reaches of the receiving streams. Values plotted are mean $( \pm$ se $)$ of concentrations of nitrate (top panel), ammonium (second panel), phosphate (third panel), and dissolved organic nitrogen (bottom panel). There were no detectable differences among watersheds or seasons, so for simplicity all values are shown as black points
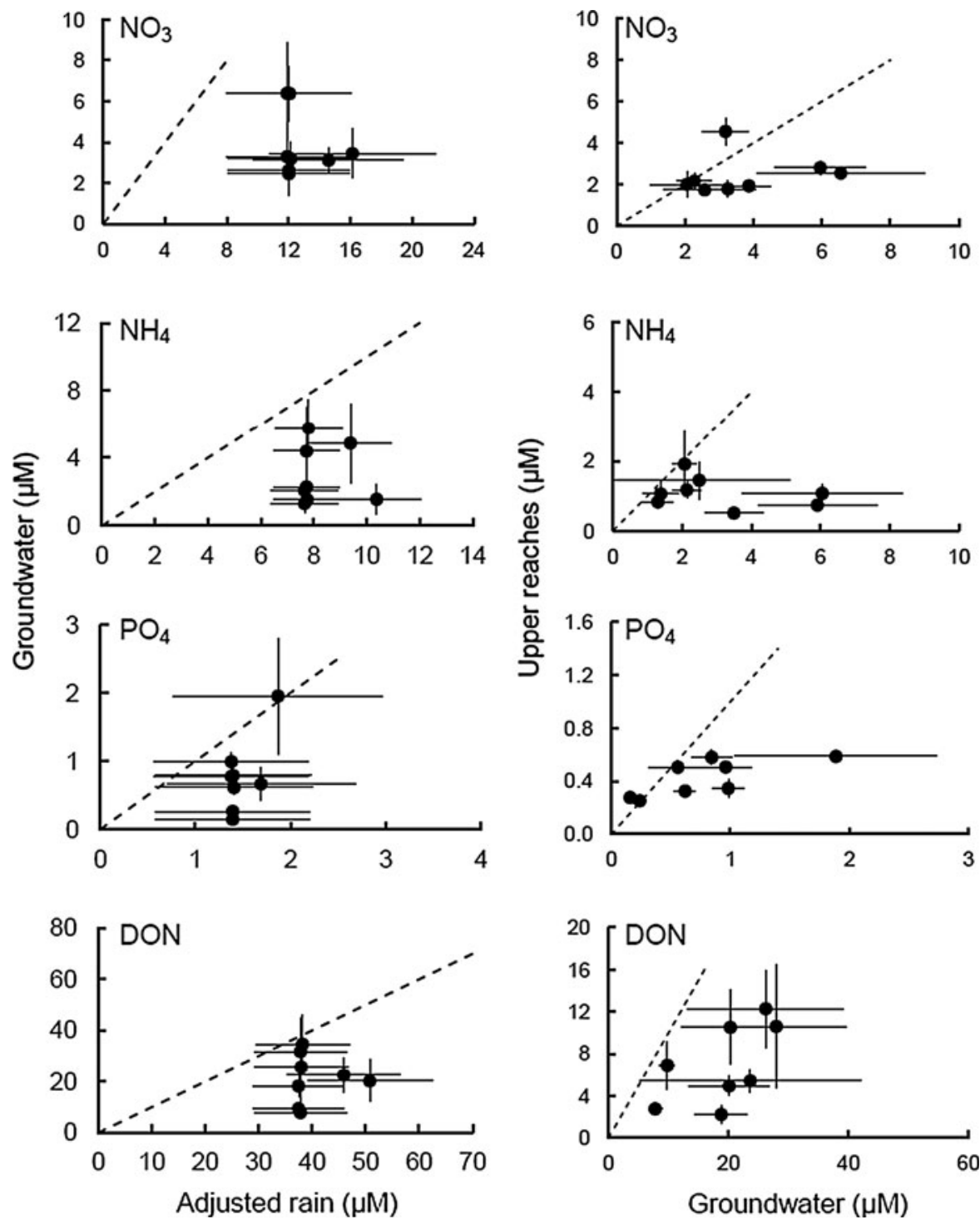

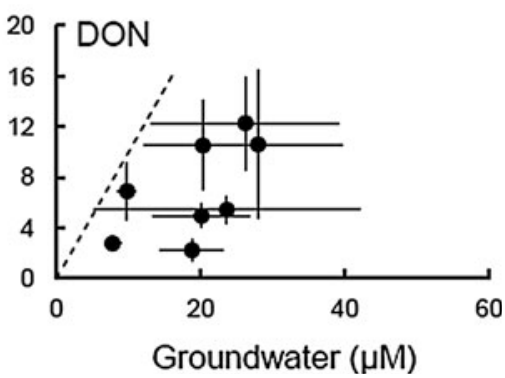

nutrients in rain (Table 2), seasonal differences were not statistically significant (Table 3). The seasonal differences in concentrations in rain falling on watershed surfaces did not survive transit within the watershed. We found no effect of area of watersheds, in contrasts to findings by Lewis et al. (1999) and Neill et al. (2011), who found relationships of nutrient concentrations emerging from watersheds to area of watershed.

Nitrate and ammonium concentrations in fresh reaches of the rios were variable, but reached higher values in more forested watersheds (Fig. 4, white points, top two panels). This result agrees with studies that found larger DIN exports from forest than from pastures (Chaves et al. 2009; Deegan et al. 2010). Dissolved organic nitrogen concentrations were highly variable, were not related to deforestation, and reached considerably higher values than those of the inorganic forms of nitrogen (Fig. 4 white points, third panel). Phosphate concentrations were low, and did not seem affected by degree of deforestation (Fig. 4 white points, bottom panel).

Concentrations of nutrients measured in the fresh reaches of the rios did not differ between dry and wet seasons (Table 3), and fell within ranges measured in other tropical streams (Table 4). Nutrient concentration in tropical streams including those in Panama, were somewhat higher than concentrations in 

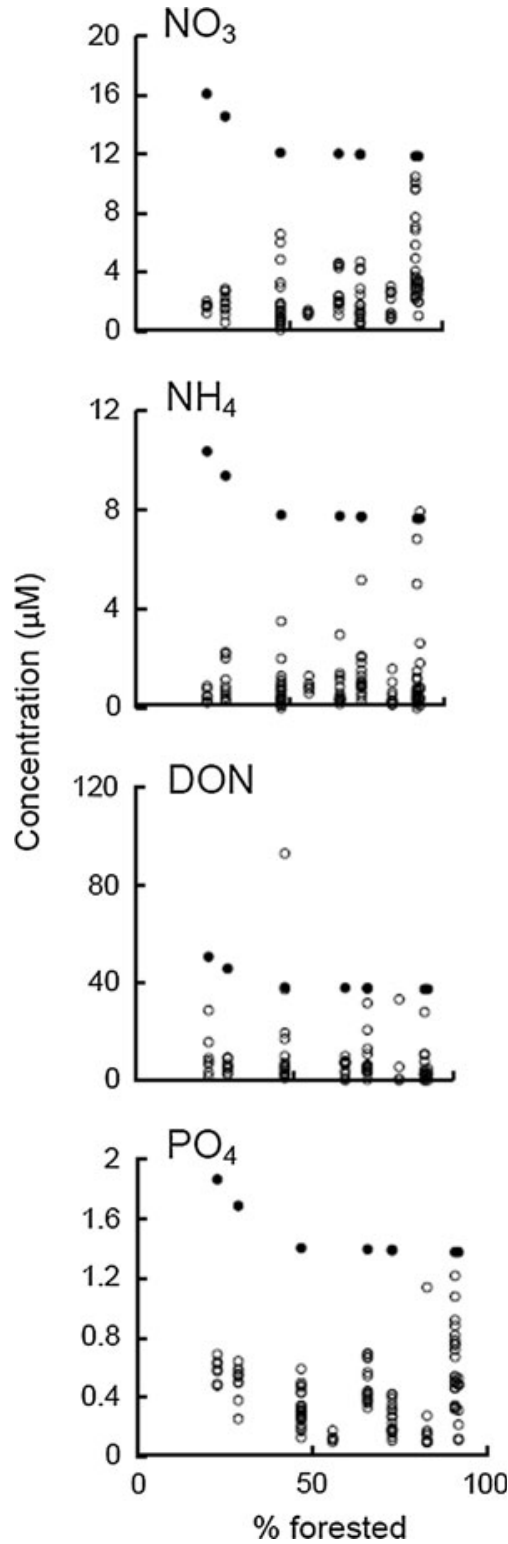

Fig. 4 Concentrations of nutrients [nitrate (top panel), ammonium (second panel), dissolved organic nitrogen (third panel), and phosphate (bottom panel)] in water from fresh reaches of the streams, plotted versus the percentage of the watershed that was forested (white points). For comparison, we included the calculated adjusted concentrations that would be entering the upper reaches of streams if there were no within-watershed losses (black points)

temperate streams (Table 4) of similar dimensions. Considering the uncertainty of the measured concentration of nutrients in tropic and temperate latitudes, the difference in geography seems less influential than hydrological and biogeochemical controls.
To assess whether there was significant withinwatershed interception of rain-derived nutrients, we compared the volume-adjusted concentrations derived from rainfall (Fig. 4, black points) to the measured concentrations in the fresh reaches of the rios (Fig. 4, white points). In all but two cases, concentrations in streams were lower than concentrations we calculated would be arriving at the edge of these receiving waters. The lower nutrient concentrations in the rios suggest considerable within-watershed retention.

Nutrient retention within watersheds

For each watershed, we calculated nutrient retention as the percent difference between volume-adjusted concentrations from rain, and concentrations measured in fresh reaches. The considerable retention of rainderived nitrogen and phosphorus within watersheds depended on degree of deforestation of watersheds, and differed for the different nutrients (Fig. 5).

Within-watershed retention of nitrate and ammonium decreased in watersheds with greater forest cover (Fig. 5 top two panels). Extrapolating from Fig. 5 (top two panels), wholly forested watersheds in our region of Panama captured 65 and $80 \%$ of rainderived nitrate and ammonium, respectively. If forests were to be entirely replaced by pastures, withinwatershed retention of nitrate and ammonium may increase to about 95 and $98 \%$.

The mechanisms that lead to differences in retention and exports of DIN in the Panamanian watersheds probably involve soil, substrate, and hydrological features (Corre et al. 2010; Wright et al. 2011), or vegetation cover (Hedin et al. 2003; Menge et al. 2009; Brookshire et al. 2012). There is much published evidence that abiotic retention, plant uptake, and microbial processes (mineralization, nitrification, dissimilatory $\mathrm{NO}_{3}$ reduction to $\mathrm{NH}_{4}$, and denitrification) within tropical forests can effectively retain nitrogen [Templer et al. (2008), among many others], yet we found that where there was greater pasture land-cover, there was less discharge of DIN.

The larger discharge of dissolved inorganic nitrogen from watersheds with larger forest cover is not conclusive evidence that forested ecosystems are "leakier" than pasture-dominated watersheds. Forested watersheds also are likely to support greater rates of free-living and symbiotic nitrogen fixation than pastures (because of larger leaf area for nitrogen- 


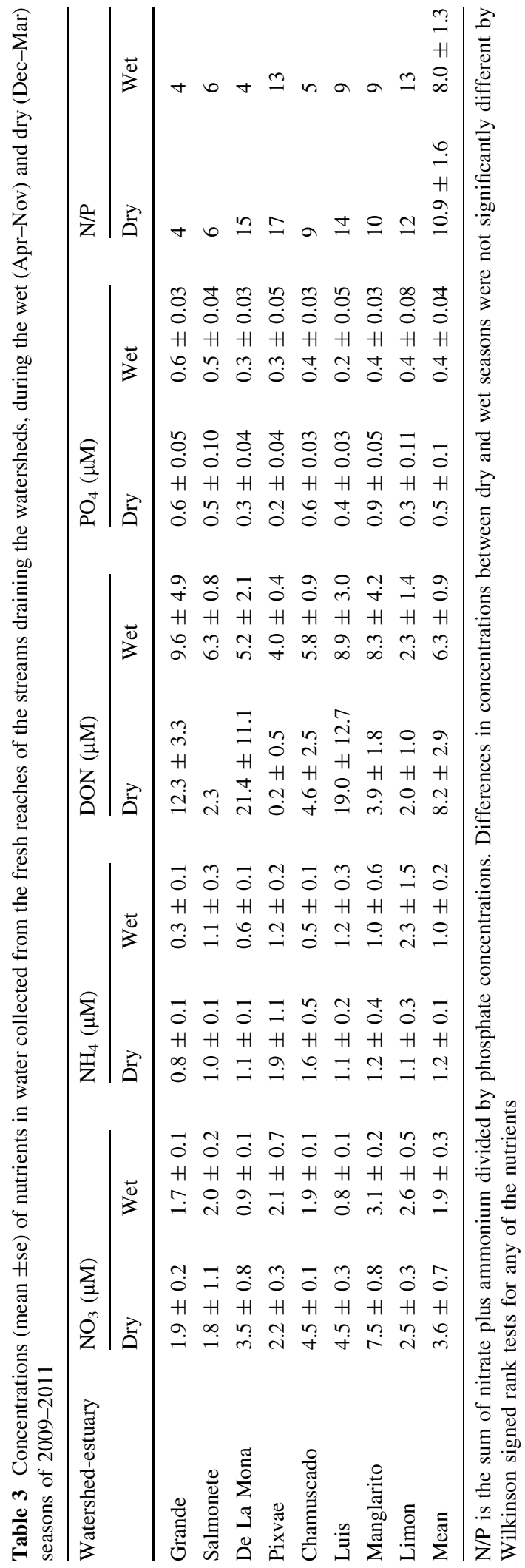

fixing blue-green bacteria and lichens, and more epiphytes, and more litter on soil), and larger surface area to collect dry atmospheric deposition. Thus, the larger hydrological loss of DIN out of forests could simply be a result of larger inputs, rather than betray different nitrogen processing within the ecosystem. There is the additional imponderable associated with within-ecosystems losses via denitrification, which could also affect "leakiness" of these tropical ecosystems. It is clear that future work needs to address $\mathrm{N}$-cycle rates before we fully understand function of these affected ecosystems (Houlton et al. 2006; Perez et al. 2006; Holtgrieve et al. 2006; Barron et al. 2009; Reed et al. 2011; Wurzburger et al. 2012).

It is difficult to explain the pattern of higher retention of DIN in the less forested Panamanian watersheds. Part of the explanation might be associated with the grasses that aggressively grow in the pastures in our area of study, and associated biogeochemical effects along flow-paths. In an Amazonian forest site Chaves et al. (2009) interpreted differences in fates of $\mathrm{NO}_{3}$ and $\mathrm{NH}_{4}$ in terms of $\mathrm{N}$-cycle processes. It is, however, difficult to generalize because there are likely to be significant local contingencies that affect fates of nutrients entering and traversing flow-paths. For example, Chaves et al. (2009) reported larger $\mathrm{NH}_{4}$, and lower $\mathrm{NO}_{3}$ in rainfall than we found, and about half the $\mathrm{NH}_{4}$ and $\mathrm{NO}_{3}$ in groundwater than we found in Panama. Concentrations of $\mathrm{NH}_{4}$ and $\mathrm{NO}_{3}$ in streams reported by Chaves et al. (2009) were about twice as large as those we found in Panama streams. Such contrasts are likely to result from local differences in activity of $\mathrm{N}$-cycle processes within each region. What seems common to both sites, though, is that regardless of differences in magnitudes of $\mathrm{NH}_{4}$ and $\mathrm{NO}_{3}$ inputs and concentrations along flow-paths of these two tropical forests, DIN discharges from forested watersheds were larger than discharges from pasturedominated watersheds.

Within-watershed retention of dissolved phosphate or organic nitrogen varied greatly, and was not related to degree of deforestation (Fig. 5 bottom two panels). The variability may owe to local biogeochemical conditions in soils and aquifer in the case of phosphate, and variation in relative unavailability or adsorption capacity of DON.

Considering all the Panama watersheds together, ignoring for the moment the relative cover of forest and pasture, we found that, on average, retention was 
Table 4 Concentrations of nutrients (mean $\mu \mathrm{M} \pm$ se for Panama, \pm sd for others, where available) in fresh reaches of streams reported in this paper and in several other tropical and temperate sites

\begin{tabular}{|c|c|c|c|c|c|c|c|}
\hline Site & Sample type & $\mathrm{NH}_{4}$ & $\mathrm{NO}_{3}$ & DON & $\mathrm{PO}_{4}$ & $\mathrm{~N} / \mathrm{P}$ & Source \\
\hline \multirow[t]{2}{*}{ Pacific coast, Panama } & $\mathrm{d}$ & $1.2 \pm 0.1$ & $3.6 \pm 0.7$ & $8.2 \pm 2.9$ & $0.5 \pm 0.1$ & $10.9 \pm 1.6$ & \multirow[t]{2}{*}{ This paper } \\
\hline & $\mathrm{w}$ & $1.0 \pm 0.2$ & $1.9 \pm 0.3$ & $6.3 \pm 0.9$ & $0.4 \pm 0.04$ & $8.0 \pm 1.3$ & \\
\hline \multirow[t]{2}{*}{ Amazon, Brazil } & $\mathrm{f}$ & $0.9 \pm 0.7$ & $6.1 \pm 1.7$ & - & - & - & \multirow[t]{2}{*}{ Deegan et al. (2010) } \\
\hline & $\mathrm{p}$ & $4.4 \pm 1.9$ & $0.7 \pm 0.3$ & - & - & - & \\
\hline \multirow[t]{2}{*}{ Amazon, Peru } & $\mathrm{d}$ & $1.6 \pm 1.6$ & $1.7 \pm 1.4$ & - & $8.3 \pm 6.0$ & 0.4 & \multirow[t]{2}{*}{ Saunders et al. (2006) } \\
\hline & $\mathrm{w}$ & $2.0 \pm 2.6$ & $0.8 \pm 2.4$ & - & - & & \\
\hline \multirow[t]{2}{*}{ Cerrado, Brazil } & $\mathrm{d}$ & 3.0 & 1.4 & - & 0.03 & 146.6 & \multirow[t]{2}{*}{ Silva et al. (2011) } \\
\hline & $\mathrm{w}$ & 4.1 & 2.8 & - & 0.2 & 34.5 & \\
\hline S. Chile and Argentina & a & 0.35 & 0.14 & $0.6-9.6$ & - & - & Perakis and Hedin (2002) \\
\hline \multirow[t]{2}{*}{ SE US } & a & 0.2 & 1.1 & - & 0.08 & 16.3 & Mulholland et al. (2000) \\
\hline & $\mathrm{a}$ & 0.8 & 1.7 & - & 0.13 & 19.2 & Houser et al. (2006) \\
\hline
\end{tabular}

For sample types, $d$ dry season, $w$ wet season, $f$ forested sites, $p$ pasture sites, $a$ annual values

about $77,85,80$, and $62 \%$ of rain-derived ammonium, nitrate, dissolved organic nitrogen, and phosphate, respectively (Fig. 5). The retention of nitrogen compounds falls within reported retention in many ecosystems. The estimated retention of phosphate, a nutrient with large capacity for adsorption to soils and sediments, is likely too low. We checked this estimate using data from Parron et al. (2011) and Giambellucca et al. (2009), to calculate that $61 \%$ of total raindelivered phosphorus was retained in a Brazilian cerrado site, a value similar to that of Fig. 5. Both these calculations likely underestimate retention, because we ignored rock weathering. In Ecuador, atmospheric deposition added $0.88 \mathrm{~kg} \mathrm{P} \mathrm{ha}^{-1}$ year $^{-1}$, while weathering contributed $0.14 \mathrm{~kg} \mathrm{P}^{-1}$ year $^{-1}$ (Borbor-Cordova et al. 2006); within watershed weathering is greater elsewhere in the tropics (Hedin et al. 2003; Porder et al. 2006). Second, we measured phosphate concentrations in bulk precipitation, which does not fully capture dry mineral dust deposition, a source that may add $82 \%$ of phosphorus deposition worldwide (Mahowald et al. 2008).

The trends in retention of atmospheric-derived nitrate and ammonium within the Panama watersheds were in a similar range, compared to retention we calculated from data from other tropical watersheds (open circles, Fig. 5). The mean retention results can be extended to say that, overall, about 23,15 , and $20 \%$ of rain-derived nitrate, ammonium, and dissolved organic nitrogen, respectively, was exported from the array of Panamanian watersheds to receiving waters of streams.

Davidson et al. (2007) showed highly N-conserving features in recovering forest covers in Brazil; in temperate latitudes, growth in recovering forests can sequester much of external $\mathrm{N}$ sources (Valiela et al. 1992, 1997). That is not the case in the Panama watersheds of this study, because tree seedlings that invade pastures are removed by selective machetting and burning. The watersheds we deal with in this paper are therefore a piebald mosaic of parcels of pastures inset in a forest matrix, with minor area of recovering forest.

Shifts in N/P in inputs and exports out of watersheds

The biologically important ratio of inorganic $\mathrm{N}$ (nitrate plus ammonium) to $\mathrm{P}$ (phosphate) falling onto the Panamanian watersheds in rain varied daily and seasonally. Rain falling on the Panamanian watersheds delivered lower N/P during the wet season compared to the dry season (Table 2). The difference was almost twofold. On average, N/P was 16.8 annually (Tables 2, 3; Fig. 6). The value we obtained for the Panama watersheds is not very different from $\mathrm{N} / \mathrm{P}=18$ reported for a Brazilian site (Parron et al. 2011).

As rain-derived nutrients coursed through the watersheds, N/P changed, and by the time nutrients 


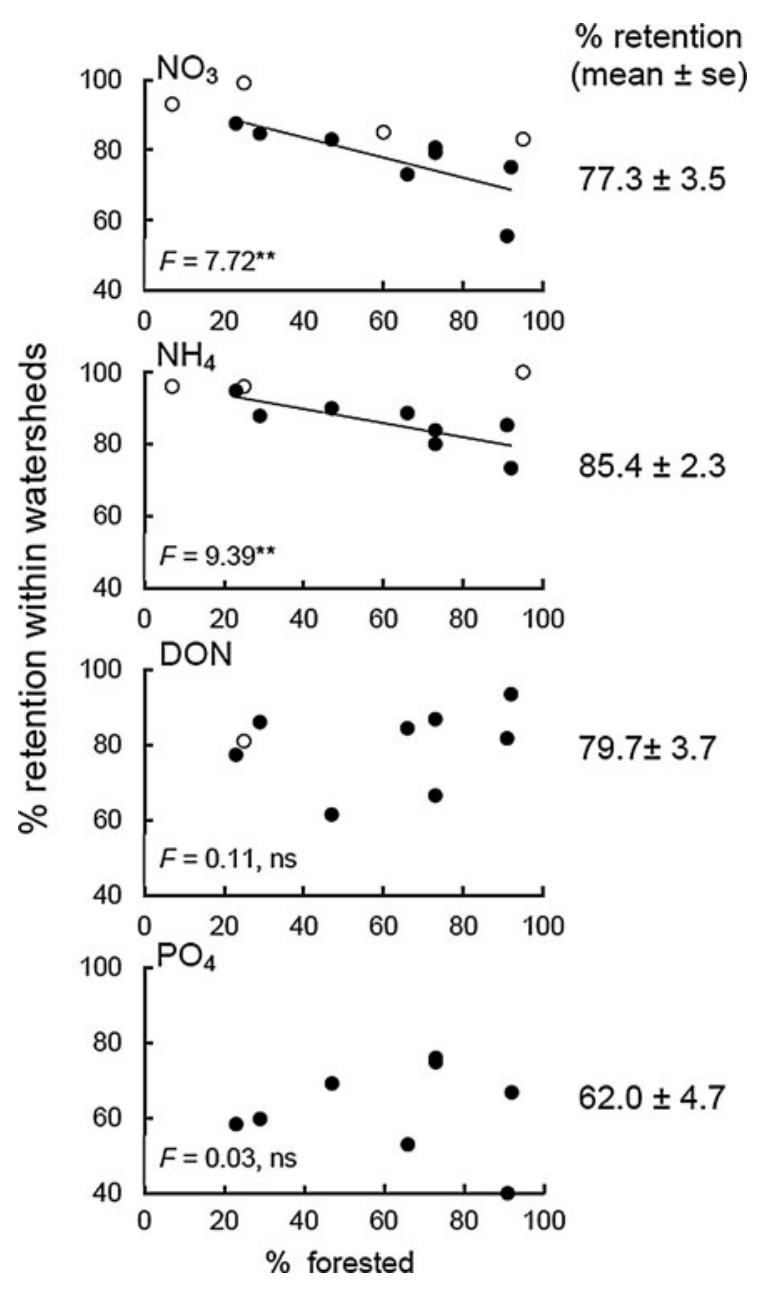

Fig. 5 Black points calculated percent retention in each watershed, for nitrate (top), ammonium (second panel), dissolved organic nitrogen (third panel), and phosphate (bottom). White points estimated retention from other tropical sites (from Rasiah et al. 2010; Heartsill-Scalley et al. 2007; Chaves et al. 2009; Deegan et al. 2010; Giambellucca et al. 2009 and Parron et al. 2011)

arrived at the headwater streams, the ratio changed substantially, but bore an imprint of watershed land cover (Fig. 6 black points). Forested watersheds delivered water-borne N/P more or less unchanged from N/P delivered by rain. In contrast, N/P were lower in water emerging from watersheds dominated by pastures.

Similar data from other tropical sites fall in similar ranges of N/P (Fig. 6 white points and Table 4). N/P values emerging from watersheds elsewhere in the tropics range from 3 to 340 (Williams et al. 1997; Downing et al. 1999; Borbor-Cordova et al. 2006;

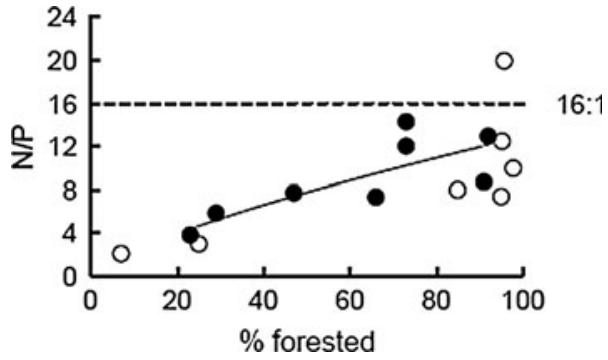

Fig. 6 Black points ratios of nitrogen (nitrate plus ammonium) to phosphorus (phosphate) in water of the upper reaches of streams versus the percent forest cover on each watershed. White points N/P from similar stream environments in different tropical sites (data from Chaves et al. 2009 and Deegan et al. 2010; Boehm et al. 2010; Parron et al. 2011)

Deegan et al. 2010; Boehm et al. 2010; Parron et al. 2011). This range in N/P suggests that $\mathrm{N}$ or $\mathrm{P}$ may have different limiting roles on the terrestrial vegetation in different sites, and implies that there will be substantially different effects of the export on down-gradient aquatic receiving ecosystems.

Fully deforested watersheds yielded stream water in the rios with N/P about 2, quite a low value. The shift to lower N/P following deforestation may come about because pasture plants are more effective at retaining nitrate and ammonium than forest vegetation. On average, N/P in the rios fell within the much larger ranges measured in other the tropical streams (Table 4), but were below the 16:1 Redfield value. This suggests that growth of producers in the rios might be N-limited. N/P in temperate streams, in contrast, averaged 16:1 (Table 4).

The retention and exports of $\mathrm{N}$ and $\mathrm{P}$ we report are additional evidence that notwithstanding the substantial nutrient retention within Panamanian watersheds, there were significant down-gradient exports to estuaries. The ratio of inorganic $\mathrm{N}$ and $\mathrm{P}$, and the magnitude of the exports, moreover, were large enough to carry biological implications, owing to the paucity of nutrients in tropical estuarine waters, and may be potentially a major mechanism that mediates coupling of land and aquatic ecosystems.

Extrapolation to total estimates of retention and exports

Earlier we noted that our calculations likely underestimated inputs of nitrogen to watersheds. One source of nitrogen that we did not measure was dry 
atmospheric deposition, which we approximated using data for tropical forests available in the literature (Table S2). We added the estimates of dry deposition of atmospheric nitrogen to those of wet deposition, so as to better approximate magnitude of inputs, retention, and exports from the Panama watersheds (Table S2, and Fig. 7). The wet plus dry results highlight two features. First, inclusion of dry deposition meaningfully increased estimated watershed retention. Second, retention of dissolved inorganic nitrogen significantly decreased in watersheds with larger forest cover (Fig. 7 top), as concluded earlier. If the estimates of inputs and retention of Fig. 7 (top) are, indeed, reasonable approximations, the corresponding exports of dissolved inorganic nitrogen (Fig. 7 bottom) might range from a low of about $10 \%$ for fully deforested watersheds to a high of about $40 \%$ of atmospheric inputs for forested watersheds.

During passage of atmospheric nitrogen though the Panama watersheds there was significant retention of DIN, as well as meaningful export of DIN. The
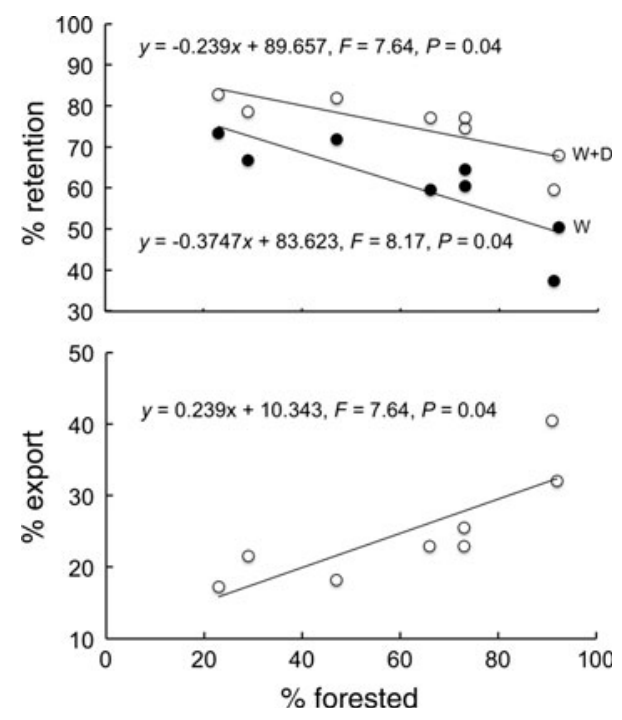

Fig. 7 Top percent retention of dissolved inorganic nitrogen, calculated from bulk wet atmospheric deposition ( $W$, black circles), and for wet plus dry atmospheric deposition $(W+D$, white circles). Wet deposition of dissolved inorganic nitrogen calculated from nitrate and ammonium values shown in Fig. 5. Dry deposition obtained from a summary of published data (see text). Retention of both wet and wet + dry deposition of DIN plotted versus percentage forest cover on the Panama watersheds (values from Table 1). Bottom estimated \% export of DIN from the Panama watersheds, derived from the open circle data of Fig. 7 top plotted versus the $\%$ forest cover relative partitioning of retained versus discharged DIN depended on degree of forest cover. If we can extrapolate from Fig. 7 (bottom), hydrological discharges from a fully forested Panamanian watershed would export about $35 \%$ of atmospheric inputs, but discharge from pasture-covered watersheds would export about $10 \%$ of atmospheric inputs. Thus, vegetation cover may be influencing a more than threefold difference in hydrological exports to receiving waters. We should be parsimonious with these conjectures, since as already mentioned above, further data on other inputs, such as symbiotic and free-living nitrogen microbial nitrogen fixation, and losses by processes such as denitrification could alter our conclusions markedly. Measurements of such nitrogen cycle processes are a necessary next step in understanding these ecosystems. Nonetheless, the data we report here provide evidence of that there is considerable retention of atmospheric nitrogen, as well as significant export of DIN from these watersheds, and that exports were higher where forests dominate tropical landscapes lacking agricultural or urban land uses.

Land use patterns in the tropics vary greatly. In some areas, forests may be being aggressively converted to agricultural lands or urbanized regions, where wastewater and use of fertilizers, and bare soils, perhaps result in increased exports of nutrients and suspended solids; our results pertain to areas where forests are replaced by quickly vegetated pastures. Where existing tropical forested areas are further converted, and maintained as pastures, the results presented here suggest that the nutrient exports to streams might well become lower, and the already nutrient-depauperate receiving waters would suffer even lower nutrient subsidies from terrestrial sources.

Acknowledgments This work was funded by NSF Grant BIO0842413; we thank Henry L. Gholz and Timothy K. Kratz of NSF for their support of this work. We would not have been able to carry out the fieldwork without the availability of the excellent resources of the Liquid Jungle Laboratory built and operated by Jean Pigozzi and the Canales de Tierra Foundation, and we are much indebted to the LJL staff for providing excellent support and facilities for our work. We thank Laurence Madin, Luis Camilli, and the Ocean Life Institute at the Woods Hole Oceanographic Institution for initial support and throughout the work. The support of the Woods Hole Consortium was instrumental to facilitating work by our interinstitutional research team. Paulina Martinetto, Rita Monteiro Oliveira, Jane Tucker, Sarah Wilkins, Sandy Baldwin, Jim Brennan, Katiuska Hernández, Richard McHorney, Sam 
Kelsey, Ned Mueller, and Jason Bissonette helped carry out the demanding field work involved in the project.Open Access This article is distributed under the terms of the Creative Commons Attribution License which permits any use, distribution, and reproduction in any medium, provided the original author(s) and the source are credited.

\section{References}

Ahlm L, Nilsson ED, Krejci R et al (2010) A comparison of dry and wet season aerosol number fluxes over the Amazon rain forest. Atmos Chem Phys 10:3063-3079

Bahn M, Reichstein M, Davidson EA et al (2010) Soil respiration at mean annual temperature predicts annual total across vegetation types and biomes. Biogeosci 7:2147-2157

Baker AR, Jickels TD, Biswas KF et al (2006) Nutrients in atmospheric aerosol particles along the AMT transect. Deep-Sea Res Part II 53:706-1719

Baker AR, Weston K, Kelly SD et al (2007) Dry and wet deposition of nutrients from the tropical Atlantic atmosphere: links to primary productivity and nitrogen fixation. Deep-Sea Res Part I 54:1704-1720

Barron AR, Wurzburger N, Bellenger JP et al (2009) Molybdenum limitation of asymbiotic nitrogen fixation in tropical forest soils. Nat Geosci 2:42-45

Boehm AB, Yamahara KM, Walters SP et al (2010) Dissolved inorganic nitrogen, soluble reactive phosphorus, and microbial pollutant loading from tropical rural watersheds in Hawai'i to the coastal ocean during non-storm conditions. Estuaries Coasts. doi:10.1007/s12237-010-9352-8

Borbor-Cordova MJ, Boyer EW, McDowell WH et al (2006) Nitrogen and phosphorus budgets for a tropical watershed impacted by agricultural land use: Guayas, Ecuador. Biogeochem 79:135-161

Bormann FH, Likens GE (1979) Catastrophic disturbance and the steady state in northern hardwood forests. Am Sci 67:660-669

Bosch JM, Hewlett JD (1982) A review of catchment experiments to determine the effect of vegetation changes on water yield and evapotranspiration. J Hydrol 55:3-23

Bowen JL, Valiela I (2001) Historical changes in atmospheric nitrogen deposition to Cape Cod, Massachusetts, USA. Atmos Environ 35:1039-1051

Bowen JL, Kroeger KD, Tomasky G et al (2007) A review of land-estuary coupling by groundwater discharge of nitrogen to New England estuaries: mechanisms and effects. Appl Geochem 22:175-191

Boy J, Rollenbeck R, Valarezo C et al (2008) Amazonian biomass burning-derived acid and nutrient deposition in the north Andean montane forest of Ecuador. Glob Biogeochem Cycles 22:GB4011

Brookshire ENJ, Gerber S, Menge DNL, Hedin LO (2012) Large losses of inorganic nitrogen from tropical rainforests suggest a lack of nitrogen limitation. Ecol Lett 15:9-16

Bruijnzeel LA (2004) Hydrological functions of tropical forests: not seeing the soil for the trees? Agric Ecosyst Environ 104:185-228

Cable JE, Bugna GC, Burnett WC et al (1996) Application of ${ }^{222} \mathrm{Rn}$ and $\mathrm{CH}_{4}$ for assessment of groundwater discharge to the coastal ocean. Limnol Oceanogr 41:1347-1353
Castroviejo S, Ibañez A (2005) Estudios Sobre la Biodiversidad de la Región de Bahía Honda (Veraguas, Panamá). Consejo Superior de Investigaciones Científicas, España

Chappell N (2010) Soil pipe distribution and hydrological functioning within the humid tropics; a synthesis. Hydrol Process 24:1567-1581

Charlier J-B, Catan P, Moussa R et al (2008) Hydrological behaviour and modeling of a volcanic tropical cultivated catchment. Hydrol Process 22:4355-4370

Chaves JE, Neill C, Germer S et al (2009) Nitrogen transformations in flow paths leading from soils to streams in Amazon forest and pasture. Ecosystems 12:961-972

Chen Y, Randerson JT, van der Werf GR et al (2010) Nitrogen deposition in tropical forests from savanna and deforestation fires. Glob Change Biol 16:2024-2030

Clark KL, Nadkarni NM, Schaefer D et al (1998) Cloud water and precipitation chemistry in a tropical montane forest, Monteverde, Costa Rica. Atmos Environ 32:1595-1603

Cleveland CC, Townsend AR (2006) Nutrient additions to a tropical rain forest drive substantial soil carbon dioxide losses to the atmosphere. Proc Natl Acad Sci USA 103:10316-10321

Cleveland CC, Townsend AR, Schimel DS et al (1999) Global patterns of terrestrial biological nitrogen $\left(\mathrm{N}_{2}\right)$ fixation in natural systems. Glob Biogeochem Cycles 13:623-645

Cleveland CC, Houlton BZ, Neill C et al (2010) Using indirect methods to constrain symbiotic nitrogen fixation rates: a case study from an Amazonian rainforest. Biogeochem 99:1-13

Corre MD, Veldkamp E, Arnold J et al (2010) Impact of elevated $\mathrm{N}$ input on soil $\mathrm{N}$ cycling and losses in old growth lowland and montane forests in Panama. Ecology 91:1715-1729

Cusack DF, Silver W, McDowell WH (2009) Biological nitrogen fixation in two tropical forests: ecosystem-level patterns and effects of nitrogen fertilization. Ecosystems 12: 1299-1315

Davidson EA, Reis de Carvalho CJ, Figueira AM et al (2007) Recuperation of nitrogen cycling in Amazonian forests following agricultural abandonments. Nature. doi:10.1028/ nature 05900

Davin EL, Noblet-Ducoudre N (2010) Climatic impact of global-scale deforestation: radiative versus non-radiative processes. J Clim 23:97-112

Deegan LA, Neill C, Haupert CL et al (2010) Amazon deforestation alters small stream structure, nitrogen biogeochemistry, and connectivity to larger rivers. Biogeochem. doi:10.1007/s10533-010-9540-4

Downing JA, McClain M, Twilley R et al (1999) The impact of accelerating land-use change on the $\mathrm{N}$-cycle of tropical aquatic ecosystems: current conditions and projected changes. Biogeochem 46:109-148

Ewel J, Berish C, Brown B et al (1981) Slash and burn impacts on a Costa Rican wet forest site. Ecology 62:816-829

Gash JHC, Nobre CA, Roberts JM et al (1996) Amazonian deforestation and climate. Wiley, Chichester

Giambellucca TW, Scholtz FG, Bucci SJ et al (2009) Evapotranspiration and energy balance of Brazilian savannas with contrasting tree density. Agric For Meteorol 149:1365-1376

Giordano JCP, Brush MJ, Anderson IC (2010) Quantifying annual nitrogen loads to Virginia's costal lagoons: source and water quality response. Estuaries Coasts 34:297-309 
Gomez-Delgado F, Roupsard O, Maire G et al (2011) Modeling the hydrological behaviour of a coffee agroforestry basin in Costa Rica. Hydrol Earth Syst Sci 15:369-392

Hasler N, Avissar R (2007) What controls evapotranspiration in the Amazon basin? J Hydrometeorol 8:380-395

Heartsill-Scalley T, Scatena FN, Estrada C et al (2007) Disturbance and long-term patterns of rainfall and throughfall nutrient fluxes in a tropical wet forest in Puerto Rico. J Hydrol 333:472-485

Hedin LO, Vitousek PM, Matson PA (2003) Nutrient losses over four million years of tropical forest development. Ecology 84:2231-2255

Hendrickx JMH, Bastiaanssen WGM, Noordman EJM et al (2005) Estimation of regional actual evapotranspiration in the Panama canal watershed. In: Harmon RS (ed) The Rio Chagres. Springer, Amsterdam, pp 315-323

Hirsch AI, Little WS, Houghton RA et al (2004) The net carbon flux due to deforestation and forest re-growth in the Brazilian Amazon: analysis using a process-based model. Glob Change Biol 10:908-924

Hofhansl F, Wanek W, Drage S et al (2010) Topography strongly affects atmospheric deposition and canopy exchange processes in different types of lowland rainforest, Southwest Costa Rica. Biogeochem. doi:10.1007/s10533010-9517-3

Holtgrieve GW, Jewett PK, Matson PA (2006) Variations in soil $\mathrm{N}$ cycling and trace gas emissions in wet tropical forests. Oecologia 146:584-594

Houlton BZ, Sigman DM, Hedin LO (2006) Isotopic evidence for large gaseous nitrogen losses from tropical rainforests. Proc Natl Acad Sci USA 103:8745-8750

Houser JN, Mulholland PJ, Maloney KO (2006) Upland disturbance affects headwater stream nutrients and suspended sediments during baseflow and stormflow. J Environ Qual 35:352-365

Hutyra LR, Munger JW, Saleska SR et al (2007) Seasonal controls on the exchange of carbon and water in an Amazonian rain forest. J Geophys Res (G Biogeosci) 112:G3

IPCC (2007) Climate change 2007: mitigation. Contribution of Working Group III to the Fourth Report of the Intergovernmental Panel on Climate Change. Cambridge University Press, Cambridge

Kauffman JB, Cummings DL, Ward DE et al (1995) Fire in the Brazilian Amazon 1: biomass, nutrient pools, and losses in slashed primary forests. Oecologia 104:397-408

Lajtha K, Seely B, Valiela I (1995) Retention and leaching losses of atmospherically-derived nitrogen in the aggrading coastal watershed of Waquoit Bay, MA. Biogeochem 28: 33-54

Latimer JS, Charpentier MA (2010) Nitrogen inputs to seventyfour southern New England estuaries: application of a watershed nitrogen-loading model. Estuarine. Coast Shelf Sci 89:125-136

LeBauer DS, Treseder KK (2008) Nitrogen limitation of net primary productivity in terrestrial ecosystems is globally distributed. Ecology 89:371-379

Lewis WM (2002) Yield of nitrogen from minimally disturbed watersheds of the United States. Biogeochem 57/58:375-385

Lewis WM, Melack JM, McDowell WH et al (1999) Nitrogen yields from undisturbed watersheds in the Americas. Biogeochem 46:149-162
Li KY, Coe MT, Ramankutty N et al (2007) Modeling the hydrological impact of land-use change in West Africa. J Hydrol 337:258-268

Loescher HW, Gholz HL, Jacobs JM et al (2005) Energy dynamics and modeled evapotranspiration from a wet tropical forest in Costa Rica. J Hydrol 315:274-294

Lovett GM (1994) Atmospheric deposition of nutrients and pollutants in North America: an ecological perspective. Ecol Appl 4:629-650

Mahowald N, Jickells TD, Baker AR et al (2008) Global distribution of atmospheric phosphorus sources, concentrations and deposition rates, and anthropogenic impacts. Glob Biogeochem Cycles 22:GB4026

Martinelli LA, Ballester MV, Krusche AV et al (1999) Land cover changes and $\delta^{13} \mathrm{C}$ composition of riverine particulate organic matter in the Piracicaba River Basin (Southeast Region of Brazil). Limnol Oceanogr 44:1826-1833

McDowell WH, Bowden WB, Asbury CE (1992) Riparian nitrogen dynamics in two geomorphologically distinct tropical rainforest watersheds-subsurface solute patterns. Biogeochem 18:53-75

Menge DNL, Pacala SW, Hedin LO (2009) Emergence and maintenance of nutrient limitation over multiple time scales in terrestrial ecosystems. Am Nat 173:164-175

Mulholland PJ, Tank JL, Sanzone DM et al (2000) Nitrogen cycling in a forest stream determined by a ${ }^{15} \mathrm{~N}$ tracer addition. Ecol Monogr 70:471-493

Neill C, Deegan LA, Thomas SM et al (2001) Deforestation for pasture alters nitrogen and phosphorus in small Amazonian streams. Ecol Appl 11:1817-1828

Neill C, Chaves JE, Biggs T et al (2011) Runoff sources and land cover change in the Amazon: an end-member mixing analysis from small watersheds. Biogeochem. doi:10.1007/ s10533-011-9597-8

Nosetto MD, Jobbágy EG, Paruelo JM (2005) Land-use change and water losses: the case of grassland afforestation across a soil textural gradient in central Argentina. Glob Change Biol 11:1101-1117

Parron LM, Bustamante MMC, Markewitz D (2011) Fluxes of nitrogen and phosphorus in a gallery forest in the Cerrado of central Brazil. Biogeochem 105:89-104

Perakis SS, Hedin LO (2002) Nitrogen loss from unpolluted South American forests mainly via dissolved organic compounds. Nature 415:416-420

Perez T, Garcia-Montiel D, Trumbore S et al (2006) Nitrous oxide nitrification and denitrification ${ }^{15} \mathrm{~N}$ enrichment factors from Amazon forest soils. Ecol Appl 16:2153-2167

Pons TL, Perreijn K, van Kessel C et al (2007) Symbiotic nitrogen fixation in a tropical rainforest: ${ }^{15} \mathrm{~N}$ natural abundance measurements supported by experimental isotopic enrichment. N Phytol 173:154-167

Porder S, Clark DA, Vitousek PM (2006) Persistence of rockderived nutrients in the wet tropical forests of La Selva, Costa Rica. Ecology 87:594-602

Rasiah V, Armour JD, Cogle AL et al (2010) Nitrate importexport dynamics in groundwater interacting with surfacewater in a wet tropical environment. Aus J Soil Res 48: 361-370

Reed SC, Cleveland CC, Townsend AR (2008) Tree species control rates of free living nitrogen fixation in a tropical rain forest. Ecology 89:2924-2934 
Reed SC, Cleveland CC, Townsend AR (2011) Functional ecology of free-living nitrogen fixation: a contemporary perspective. Annu Rev Ecol Evol Syst 42:480-512

Roggy JC, Prévost MF, Garbaye J et al (1999) Nitrogen cycling in the tropical rain forest of French Guiana: comparison of two sites with contrasting soil types using $\delta^{15} \mathrm{~N}$. J Trop Biol 15:1-22

Saunders TJ, McClain ME, Llerena CA (2006) The biogeochemistry of dissolved nitrogen, phosphorus, and organic carbon along terrestrial-aquatic flowpaths of a montane headwater catchment in the Peruvian Amazon. Hydrol Process 20:2549-2562

Scanlon BR, Jolly I, Sophocleous M et al (2007) Global impacts of conversions from natural to agricultural ecosystems on water resources: quantity versus quality. Water Resour Res 43:W03437. doi:10.1029/2006WR005486

Sigha-Nkamdjou L, Galy-Lacaux C, Pont V et al (2003) Rainwater chemistry and wet deposition over the Equatorial forested ecosystem of Zoétélé (Cameroon). J Atmos Chem 46:173-198

Silva JSO, da Cunha Bustamante MM, Markewitz D et al (2011) Effects of land cover on chemical characteristics of streams in the Cerrado region of Brazil. Biogeochemistry 105:75-88

Sumner DM, Jacobs JM (2005) Utility of Penman-Monteith, Priestley-Taylor, reference evapotranspiration, and pan evaporation methods to estimate pasture evapotranspiration. J Hydrol 308:81-104

Sun G, Zhou G, Zhang Z et al (2006) Potential water yield reduction due to forestation across China. J Hydrol 328: 548-558

Sundarambal P, Tkalich P, Balasubramanian R (2010) Impact of biomass burning on ocean water quality in Southeast Asia through atmospheric deposition: eutrophication modeling. Atmos Chem Phys 10:11337-11357

Templer P, Silver W, Pet-Ridge J, DeAngelis K, Firestone M (2008) Plant and microbial controls on nitrogen retention and loss in a humid tropical forest. Ecology 89:3030-3040

Valiela I, Foreman K, Lamontagne M et al (1992) Couplings of watersheds and coastal waters: sources and consequences of nutrient enrichment on Waquoit Bay, Massachusetts. Estuaries 15:443-457

Valiela I, Collins G, Kremer K et al (1997) Nitrogen loading from coastal watershed to receiving estuaries: new method and application. Ecol Appl 7:358-380

Valiela I, Geist M, McClelland J et al (2000) Nitrogen loading from watersheds to estuaries: verification of the Waquiot Bay nitrogen-loading model. Biogeochem 49:277-293

Vitousek PM, Howarth RW (1991) Nitrogen limitation in land and sea: how can it occur? Biogeochem 13:87-115

Vitousek PM, Reiners WA (1975) Ecosystem succession and nutrient retention: a hypothesis. BioSci 25:376-381

Vorosmarty CJ, Fekete BM, Meybeck M et al (2000) Global system of rivers: it role in organizing continental land mass and defining land-to-ocean linkages. Glob Biogeochem Cycles 14:599-621

Wassenaer T, Gerber P, Verburg PH et al (2007) Projecting land use changes in the Neotropics: the geography of pasture expansion into forest. Glob Environ Change 17:86-104

Williams MR, Fisher TR, Melack JM (1997) Chemical composition and deposition of rain in the central Amazon. Biogeochem 38:67-102

Wolf S, Eugster W, Potvin C et al (2011) Carbon sequestration potential of tropical pasture compared with afforestation in Panama. Glob Change Biol 17:2763-2780

Wright SJ, Yavitt JB, Wurzburger N et al (2011) Potassium, phosphorus, or nitrogen limit root allocation, tree growth, or litter production in lowland tropical forest. Ecology 92:1616-1625

Wullaert H, Homeier J, Valarezo C et al (2010) Response of the $\mathrm{N}$ and $\mathrm{P}$ cycles of an old-growth montane forest in Ecuador to experimental low-level $\mathrm{N}$ and $\mathrm{P}$ amendments. For Ecol Manag 260:1434-1445

Wurzburger N, Bellenger JP, Kraespiel AML et al (2012) Molybdenum and phosphorus interact to constrain asymbiotic nitrogen fixation in tropical forests. PLoS One 7:1-7

Zhang L, Dawes WR, Walker GR (2001) Response of mean annual evapotranspiration to vegetation changes at catchment scales. Water Resour Res 37:701-708 